\title{
EPIDURAL LABOUR ANALGESIA WITH LOW DOSE OF BUPIVACAINE WITH LOW DOSE OF FENTANYL VS BUTORPHANOL
}

\author{
Simrit Kaur1, Tejinderpal Kaur Grewal2, Sandeep Kaur Sidhu³, Navneet Kumari ${ }^{4}$, Jyoti Nara ${ }^{5}$
}

${ }_{1}^{1}$ Assistant Professor, Department of Anaesthesia, Government Medical College and Hospital, Patiala, Punjab, India. ${ }^{2}$ Associate Professor, Department of Anaesthesia, Government Medical College and Hospital, Patiala, Punjab, India. 3 Junior Resident, Department of Anaesthesia, Government Medical College and Hospital, Patiala, Punjab, India. ${ }^{4}$ Consultant Anaesthetist, Deep Hospital, Ludhiana, Punjab, India.

5Junior Resident, Department of Anaesthesia, Government Medical College and Hospital, Patiala, Punjab, India.

ABSTRACT
BACKGROUND
Epidural analgesia is the most commonly accepted and used technique for painless labour. Local anaesthetic bupivacaine when
combined with low dose of opioid analgesics gives excellent results.
The aim of this study is to evaluate and compare the efficacy and safety of epidural fentanyl vs butorphanol for painless labour
and effect on newborn (Apgar score).
Settings and Design - Randomised double-blind trial.

\section{MATERIALS AND METHODS}

50 parturients were randomly allocated in two groups. Group I: receive epidurally $15 \mathrm{~mL}$ bupivacaine $0.0625 \%+$ fentanyl $30 \mathrm{mcg}$ and Group II: receive epidurally $15 \mathrm{~mL}$ bupivacaine $0.0625 \%$ + butorphanol $1 \mathrm{mg}$.

\section{RESULTS}

The mean onset of analgesia was faster in Group I, whereas duration of analgesia was longer in Group II. There was no incidence of motor block, high rate of Normal Vaginal Delivery and very low incidence of forceps application or LSCS in both the groups. Somnolence was the main side effect in Group II and other side effects were seen equally in both groups.

\section{CONCLUSION}

The addition of low dose of opioids has greatly improved the quality of labour analgesia and at the same time reduced the incidence of instrumental deliveries and LSCS without depressing the neurobehavioral status of the newborn.

\section{KEYWORDS}

Fentanyl, Butorphanol, Epidural, Bupivacaine.

HOW TO CITE THIS ARTICLE: Kaur S, Grewal TK, Sidhu SK, et al. Epidural labour analgesia with low dose of bupivacaine with low dose of fentanyl vs butorphanol. J. Evolution Med. Dent. Sci. 2017;6(10):796-798, DOI: 10.14260/Jemds/2017/172

\begin{tabular}{ll}
\hline BACKGROUND & narcotic with weak $\mu$ receptor agonist and antagonist activity \\
Experience of pain during childbirth is a natural & $\begin{array}{l}\text { and strong kappa receptor agonist has been proved to be a } \\
\text { useful and safe adjunct to bupivacaine used for epidural }\end{array}$ \\
phenomenon. Epidural analgesia is the most commonly \\
accepted and used technique for painless labour. Using this
\end{tabular}
technique, good analgesia may be achieved at any stage of labour without incurring undue maternal or foetal depression.(1) With the advent of new longer-acting local anaesthetic bupivacaine, this technique has become more popular. This local anaesthetic when combined with low dose of epidural opioid analgesics gives excellent results. The current use of fentanyl with local anaesthetic gives safe analgesia, while motor block is avoided. Fentanyl acts as agonist at opioid receptors at presynaptic and postsynaptic sites in CNS, principally the brainstem and spinal cord and 3 cause decrease in neurotransmission. Butorphanol, a lipid

Financial or Other, Competing Interest: None.

Submission 15-12-2016, Peer Review 19-01-2017,

Acceptance 25-01-2017, Published 02-02-2017.

Corresponding Author:

Dr. Simrit Kaur,

Assistant Professor,

Department of Anaesthesia,

Government Medical College and Hospital,

Patiala, Punjab,

India.

E-mail: drsimrit29@gmail.com

DOI: $10.14260 /$ jemds $/ 2017 / 172$

\section{MATERIALS AND METHODS}

After Institutional Ethical approval and written informed consent, 50 full-term parturient of ASA Grade I and II with spontaneous onset of labour were included in this prospective, randomised, double-blind trial. Parturient with cephalopelvic disproportion (CPD), contracted pelvis, pregnancy-induced hypertension (PIH), active phase of labour, foetal distress, coagulopathy, hypersensitivity to local anaesthetics or studied drugs and any contraindication to epidural anaesthesia were excluded from the study. In sitting position after all aseptic precautions, 18-G Epidural needle was introduced in L3-L4 interspace. After confirmation of correct position of needle by loss of resistance technique, epidural catheter was advanced into epidural space and secured at desired length. When labour was well established, allocated drugs were given to respective groups. On patient demand, top-up was given. All patients were randomised (computer generated randomisation and concealment via sealed opaque envelope technique) into two equal groups $(\mathrm{n}=25)$ : Group I: To receive $15 \mathrm{~mL}$ of bupivacaine $.0625 \%+$ fentanyl $30 \mathrm{mcg}$ through epidural catheter and top up doses of $10 \mathrm{~mL} .0625 \%$ + fentanyl $10 \mathrm{mcg}$ was given as and when 
required Group II: To receive $15 \mathrm{~mL}$ of bupivacaine $.0625 \%+$ butorphanol $1 \mathrm{mg}$ through epidural catheter and Top up doses of $10 \mathrm{~mL} .0625 \%$ + butorphanol $0.6 \mathrm{mg}$ was given as and when required. Haemodynamic parameters (BP, PR) were recorded every 5 mins. for 30 minutes after first injection and then every 30 mins. Foetal heart rate was also monitored at every 30 mins. interval during first stage and every 5 mins. during second stage. Analgesia was measured with VAS. Pain was assessed by VAS $(0-10)$ on which 0 indicates "no pain" and 10 indicates "maximum pain." Time of onset of analgesia (time from the injection of drugs into epidural space up to the time when desired level of analgesia is achieved or diminished sensation to pin prick in any of required dermatomes), level of analgesia (highest level of dermatome up to which no pinprick sensation was appreciated was labelled as upper level of analgesia) and duration of analgesia (Time from onset of analgesia to return of pain of uterine contraction felt by parturients) were recorded. Motor block was assessed using Bromage scale 30 mins. after injection of drug in epidural space and in 1 st and 2nd stage of labour.

- Grade 0 - No motor block.

- Grade 1 - Impaired hip flexion, normal knee and ankle movement.

- Grade 2 - Impaired hip and knee movements, normal ankle movements.

- Grade 3 - Impaired hip, knee and ankle joint movements.

Any maternal side effects like motor block, bradycardia, hypotension (Fall in BP more than $30 \mathrm{mmHg}$ of pre-epidural $\mathrm{BP}$ or fall of BP below $100 \mathrm{mmHg}$ ) were recorded. Systemic side effects like light headedness, anxiety, restlessness, circumoral numbness, nausea, somnolence were also observed and recorded if present.

\section{RESULTS}

Descriptive statistics was done for all data and were reported in terms of mean values and percentages. Continuous variables were analysed with unpaired ' $t$ ' test. Categorical variables were analysed with chi-square test and Fischer Exact test. Statistical significance was taken as $p<0.05$.

\begin{tabular}{|c|c|c|c|c|}
\hline Group & No. of Cases & Range & Mean \pm SD & P value \\
\cline { 1 - 4 } I & 25 & $20-25$ & $22.56 \pm 1.63$ & \multirow{2}{*}{$>0.05$} \\
\hline II & 25 & $19-32$ & $22.76 \pm 3.05$ & \\
\cline { 1 - 1 } Table 1. Age Incidence \\
\hline
\end{tabular}

Mean age was similar in two groups. The values were statistically insignificant.

Mean time of onset of analgesia was $11.60 \pm 1.87 \mathrm{~min}$ in Group I and 15.6 $\pm 2.16 \mathrm{~min}$ in Group II. The difference in onset of analgesia was statistically highly significant. Mean duration of analgesia was $71.40 \pm 9.30 \mathrm{~min}$ in Group I and $116 \pm 13.22 \mathrm{~min}$ in Group II. The difference in Mean duration of analgesia was (Table 2) statistically significant. Mean requirement of top-ups was $3.0 \pm 1.17$ in Group I and $2.30 \pm$ 1.01 in Group II. Statistically, this difference between two groups is significant. Injection delivery interval, assessment of neonates using Apgar score at $1 \mathrm{~min}$ and 5 mins. was comparable in both groups. Statistically, these results were not significant.

\begin{tabular}{|c|c|c|c|}
\hline & Group I & Group II & P value \\
\hline $\begin{array}{c}\text { Time of onset } \\
\text { of analgesia } \\
\text { (mins.) } \\
\text { Mean } \pm \text { SD }\end{array}$ & $11.60 \pm 1.87$ & $15.60 \pm 2.16$ & $<0.01$ \\
\hline $\begin{array}{c}\text { Duration of } \\
\text { analgesia } \\
\text { (mins) } \\
\text { Mean } \pm \text { SD }\end{array}$ & $71.40 \pm 9.30$ & $116.0 \pm 13.22$ & $<0.01$ \\
\hline $\begin{array}{c}\text { Total no of top- } \\
\text { up doses } \\
\text { required }\end{array}$ & $3.0 \pm 1.17$ & $2.30 \pm 1.01$ & $<0.05$ \\
\hline $\begin{array}{c}\text { Injection } \\
\text { delivery } \\
\text { interval (mins.) } \\
\text { Mean } \pm \text { SD }\end{array}$ & $244.12 \pm 91.12$ & $285.95 \pm 120.32$ & $>0.05$ \\
\hline $\begin{array}{c}\text { Apgar score at } \\
\text { 1 min. }\end{array}$ & $7.64 \pm 0.80$ & $7.52 \pm 1.44$ & $>0.05$ \\
\hline $\begin{array}{c}\text { Apgar score at } \\
5 \text { mins. }\end{array}$ & $8.76 \pm 0.59$ & $8.84 \pm 0.62$ & $>0.05$ \\
\hline \multicolumn{2}{|c|}{ Table 2 } & \\
\hline
\end{tabular}

As shown in Table 3, 4, 5 there was no statistically significant difference of pulse rate and SBP between two groups before injection and after injection. However, the difference in PR and SBP in both groups before and after injection was statistically significant. Motor blockade was assessed using Bromage scale and Grade 0 was seen 30 mins. after injection in all patients of both groups.

No case of somnolence was observed in Group I and 10 cases in Group II. This difference is statistically significant.

\begin{tabular}{|c|c|c|c|c|}
\hline Period & $\begin{array}{c}\text { Group } \\
\text { I }\end{array}$ & $\begin{array}{c}\text { Group } \\
\text { II }\end{array}$ & $\begin{array}{c}\text { P } \\
\text { value }\end{array}$ & Significance \\
\hline $\begin{array}{c}\text { PR } \\
\text { before } \\
\text { injection }\end{array}$ & $92.96 \pm 8.10$ & $88.88 \pm 7.35$ & $>0.05$ & NS \\
\hline $\begin{array}{c}\text { PR after } \\
\text { injection }\end{array}$ & $83.76 \pm 6.74$ & $80.72 \pm 6.34$ & $>0.05$ & NS \\
\hline $\begin{array}{c}\text { SBP } \\
\text { before } \\
\text { injection }\end{array}$ & $125.92 \pm 11.11$ & $128.96 \pm 9.14$ & $>0.05$ & NS \\
\hline $\begin{array}{c}\text { SBP } \\
\text { after } \\
\text { injection }\end{array}$ & $118.08 \pm 10.17$ & $120.64 \pm 8.99$ & $>0.05$ & NS \\
\hline \multicolumn{5}{|c|}{ Table 3 } \\
\hline
\end{tabular}

\begin{tabular}{|c|c|c|c|c|}
\hline Period & $\begin{array}{c}\text { PR Before } \\
\text { Injection }\end{array}$ & $\begin{array}{c}\text { PR After } \\
\text { Injection }\end{array}$ & $\begin{array}{c}\text { P } \\
\text { value }\end{array}$ & Significance \\
\hline $\begin{array}{c}\text { Group } \\
\text { I }\end{array}$ & $92.96 \pm 8.10$ & $83.76 \pm 6.74$ & $\begin{array}{c}< \\
0.05\end{array}$ & $\mathrm{~S}$ \\
\hline $\begin{array}{c}\text { Group } \\
\text { II }\end{array}$ & $88.88 \pm 7.35$ & $80.72 \pm 6.34$ & $\begin{array}{c}< \\
0.05\end{array}$ & $\mathrm{~S}$ \\
\hline \multicolumn{5}{|c|}{ Table 4 } \\
\hline
\end{tabular}

\begin{tabular}{|c|c|c|c|c|}
\hline Period & $\begin{array}{c}\text { SBP Before } \\
\text { Injection }\end{array}$ & $\begin{array}{c}\text { SBP After } \\
\text { Injection }\end{array}$ & $\begin{array}{c}\text { P } \\
\text { value }\end{array}$ & Significance \\
\hline $\begin{array}{c}\text { Group } \\
\text { I }\end{array}$ & $125.92 \pm 11.11$ & $118.08 \pm 10.17$ & $<0.05$ & $\mathrm{~S}$ \\
\hline $\begin{array}{c}\text { Group } \\
\text { II }\end{array}$ & $128.96 \pm 9.14$ & $120.64 \pm 8.99$ & $<0.05$ & $\mathrm{~S}$ \\
\hline \multicolumn{5}{|c|}{ Table 5 } \\
\hline
\end{tabular}




\section{DISCUSSION}

Labour analgesia is often provided by epidural administration of local anaesthetic and opioid solutions. An opioid is combined with local anaesthetic to reduce local anaesthetic requirements and side effects including systemic toxicity, hypotension and motor blockade.

In the present study, mean time taken for onset of analgesia was $11.60 \pm 1.87$ mins. in Group I which was significantly less than when compared to Group II which was $15.60 \pm 2.16$ mins. Our results are in concordance with Campbell et al(3) and Hunt et al.(2)

Mean duration of analgesia was $71.40 \pm 9.30$ mins. In Group I which was significantly shorter than Group II which was $116 \pm 13.22$ mins. Our results are in concordance with Breen et al,(4) James et al(5) and Kizilarslan et al.(6)

Maternal SBP and PR decreased following analgesia in both groups, but with no difference between the groups. No patient in any of the groups had hypotension or bradycardia. Our results are in concordance with Casio et al(7) and Deschamps et al.(8)

All the patients in both groups had no motor block. So all the patients had walking epidural. Our results are in concordance with Chestnut et al,(9) Rodriguez et al,(10) James et al(5) and Campbell et al.(3)

The major side effects encountered were somnolence, nausea, emesis and retention urine. Somnolence was the main side effect in Group II. None of the patients in Group I had somnolence. Nausea, emesis and retention urine were seen in both groups. Our results are in concordance with Crawford et al,(11) Justin et al(12) and Campbell et al.(3)

24 parturients in Group I had spontaneous NVD, while 22 parturients in Group II had NVD. The incidence of forceps delivery and LSCS was greatly reduced in both groups. Our results are in concordance with Chestnut et al,(9) Rodriguez et al,(10) James et al(5) and Justin et al.(12)

In Group I, new borns with Apgar score $\geq 7$ at 1 min were $84 \%$, while with Apgar score $\geq 7$ at 5 mins. were $100 \%$. In Group II, new borns with Apgar score $\geq 7$ at 1 min were $88 \%$, while with Apgar score $\geq 7$ at 5 mins. were $92 \%$. Assessment of neonates using Apgar score at 1 min and 5 mins. was comparable in both groups. Our results are in concordance with Chestnut et al(9) and Murphy et al.(13)

\section{CONCLUSION}

The combination of low dose of local anaesthetic with lowdose opioids have provided consistent, effective and safe labour analgesia without causing clinically significant adverse maternal or foetal side effects. Time taken for onset of analgesia was shorter with fentanyl than butorphanol and duration of analgesia was longer with butorphanol than fentanyl. The addition of low dose of opioids has greatly improved the quality of labour analgesia at the same time reduced the incidence of instrumental deliveries and LSCS without depressing the neurobehavioural status of the new born.

\section{REFERENCES}

[1] Bonica JJ, Veland K. Heart disease. In: Bonica JJ. Principles and practice of obstetric analgesia and anaesthesia. Vol. 2. Philadelphia: FA Davis 1969:p.167.

[2] Hunt CO, Naulty JS, Malinow AM, et al. Epidural butorphanol-bupivacaine for analgesia during labor and delivery. Anesth Analg 1989;68(3):323-7.

[3] Campbell DC, Zwack RM, Crone LA, et al. Ambulatory labor epidural analgesia: bupivacaine versus ropivacaine. Anesth Analg 2000;90(6):1384-9.

[4] Breen TW, Shapiro T, Glass B, et al. Epidural anesthesia for labor in an ambulatory patient. Anesth Analg 1993;77(5):919-24.

[5] James KS, McGrady E, Quasim I, et al. Comparison of epidural bolus administration of $0.25 \%$ bupivacaine and $0.1 \%$ bupivacaine with $0.0002 \%$ fentanyl for analgesia during labour. Br J Anaesth 1998;81(4):507-10.

[6] Kizilarslan S, Kuvaki B, Onat U, et al. Epidural fentanyl bupivacaine compared with clonidine-bupivacaine for analgesia in labour. Eur J Anaesthesiol 2000;17(11):692-7.

[7] Cascio M, Pygon B, Bernett C, et al. labour analgesia with intrathecal fentanyl decreases maternal stress. Can J Anaesth 1997;44(6):605-9.

[8] Deschamps A, Kaufman L, Backman SB, et al. Autonomic nervous system response to epidural analgesia in labouring patients by wavelet transform of heart rate and blood pressure variability. Anaesthesiology 2004;101(1):21-7.

[9] Chestnut DH, Owen CL. Bates JN, et al. Continuous infusion epidural analgesia during labour: a randomized, double- blind comparison of $0.0625 \%$ bupivacaine $/ 0.0002 \%$ fentanyl versus $0.125 \%$ bupivacaine. Anaesthesiology 1988;68(5):754-9.

[10] Rodriguez J, Abboud TK, Reyes A, et al. Continuous infusion epidural anaesthesia during a labour: a randomized, double blind comparison of $0.0625 \%$ bupivacaine $/ 0.002 \%$ butorphanol and $0.125 \%$ bupivacaine. Reg Anaesthesia 1990;15(6):300-3.

[11] Crawford JS. Principles and practice of obstetric anaesthesia. $3^{\text {rd }}$ edn. Oxford Blackweel Scientific Publication 1972:472-475.

[12] Justin DM, Knott C, Luchman J. Epidural versus intramuscular fentanyl: analgesia and pharmacokinetics in labour. Anaesthesia 1983;38(10):937-42.

[13] Murphy JD, Henderson K, Bowden MI, et al. Bupivacaine versus bupivacaine plus fentanulfor epidural analgesia: effect on maternal satisfaction. BMJ 1991;302:564-8. 